\title{
Users or producers of ecosystem services? A scenario exercise for integrating conservation and reindeer herding in northeast Finland
}

Hannu I Heikkinen ${ }^{1}$, Simo Sarkki ${ }^{2^{*}}$ and Mark Nuttall ${ }^{3}$

* Correspondence: simo.sarkki@oulu.fi ${ }^{2}$ Thule Institute, University of Oulu, PO Box 730090014, Oulu, Finland Full list of author information is available at the end of the article

\begin{abstract}
Nature conservation is often seen as incompatible with pastoralism: conserved predators can cause significant harm to livestock, or livestock may conquer space from natural species. Currently, nature conservation and related policies are increasingly framed through the notion of ecosystem services, which form basis for human well-being. What are the implications of this framing in the relationships between pastoralism and conservation? To answer this question, we draw from our previous research to build four scenarios on the relationships between reindeer herding and nature conservation in northeast Finland. In the two ecosystem service, 'user' scenarios reindeer herders are seen to degrade nature, and thus should be controlled. In the first scenarios, reindeer herding is still compensated for its losses to predation, but in the second scenario, 'reindeer farming' and free grazing practises are eroded for achieving conservation objectives. If herding is viewed as a producer of ecosystem services, the herders' incentivised function would be to sustain predator populations and resemble natural species (wild forest reindeer). In our two 'producer' scenarios, new professions as ecosystem stewards or as ecotourism entrepreneurs emerge and herding changes from meat production priority to supporting the production of other ecosystem services. Novel solutions to conservation-pastoralism dilemmas might emerge if pastoral communities are seen as potential producers of ecosystem services. However, 'producer-based' conservation practises also include various uncertainties and might have negative impacts on pastoral communities' well-being, especially on the continuity of social and cultural traditions.
\end{abstract}

Keywords: Predators, Semi-domesticated reindeer, Wolf, bear, Ecosystem services, compensations systems, Payments for ecosystem services

\section{Background}

Nature conservation and pastoralism are often considered incompatible and contradictory (e.g. Thompson 1993; Newmark et al. 1994; Buller 2008; Skogen et al. 2008). In many cases, contradiction tends to arise from the restrictions that conservation, and the protected areas are felt to impose on pastoralism and the livelihoods of pastoralists or from the negative effects that predator conservation has on livestock. Often viewed as ecologically and symbolically important, predator animals are becoming the common objectives of nature conservation policies. In northern Finland, there is rising

\section{至 Springer}

(c) 2012 Heikkinen et al.; licensee Springer. This is an Open Access article distributed under the terms of the Creative Commons Attribution License (http://creativecommons.org/licenses/by/2.0), which permits unrestricted use, distribution, and reproduction in any medium, provided the original work is properly cited. 
local anxiety that predators such as wolves, brown bears, lynx and wolverines are posing a threat to reindeer herding (Bisi et al. 2007; Sandström et al. 2009; Heikkinen et al. 2011; Hiedanpää and Bromley 2011). In addition, discussions that herding should be restricted in conservation areas are also provoking considerable debate about the rights of reindeer herders and the viability of local livelihoods in the future (Heikkinen et al. 2010; Sarkki 2011; Sarkki et al. In press). More widely in Europe where successful biodiversity conservation has long been considered to be inextricably linked to the existence of protected areas, biodiversity is declining despite widespread protected areas coverage - it is argued that the failure of protected areas management is due largely to its neglect of local people's perspectives and participation and the absence of any benefits to the local communities (Hirschnitz-Garbers and Stoll-Kleemann 2011).

Nature conservation agencies increasingly frame discussions of nature conservation not merely in terms of species or area conservation but with the idea of ecosystem services (Daily 1997; Costanza et al. 1997; Millennium Ecosystem Assessment 2003). Ecosystem services encompass benefits of nature to people, and they are often classified in four categories: provisioning, cultural, regulating and supporting services. The key point is that nature conservation is no longer justified just because of nature's intrinsic value but because of the benefits nature provides for humans. Indeed, the ecosystem service approach is increasingly applied to environmental policies of, for example, the European Union and by many nature conservation organisations, initiatives and nongovernment organizations (NGOs). The rise of the ecosystem services approach is very much a part of both the rethinking of new conservation measures and new ways of conceptualising human-environment relations by the International Conservation and Policy Communities (see European Union (EU) Nature \& Biodiversity Partnerships 2009; WWF (2010); Convention on Biological Diversity (CBD) (2010); Countdown 2010). It is thus an increasingly interesting question as to how this new framing of human-environment relations influences and impacts pastoralism-nature conservation relationships. Will the ecosystem service approach make pastoralism more compatible with conservation efforts than previous attempts? How does the ecosystem service approach affect the relationships between nature conservation policies, communities, ecosystems and species; what are the related uncertainties behind the promises of the ecosystem service framework?

To address these questions, we recognise four plausible future development trends for how nature conservation agencies could apply the ecosystem service framework in northeast Finland. We examine how these four scenarios would have effects and impacts on reindeer herding and its relation to nature conservation. We have two reasons for using the ecosystem services framework. Firstly, as pointed out, nature conservation and related policies are increasingly framed by the ecosystem service perspective, and we argue that this will also impact on the already fraught relations between pastoralism and nature conservation. Secondly, we use the ecosystem service approach as an analytical tool to structure our scenarios, and we consider this to serve as an innovative way to rethink the topical relationships between species, ecosystems, communities and policies.

Our case study concerns Finnish reindeer herding near the Russian border, particularly with reference to recent developments related to and affecting Oulanka National Park (ONP). Our scenarios are based on our previous research on trends and 
developments in reindeer herding and nature conservation in Finland and are informed by two key uncertainties. The first uncertainty encompasses how and with what effects reindeer herding could be modified from being seen as a user of ecosystem services to being viewed and accepted as a producer of certain ecosystem services, an idea that resonates with the traditional biotope and landscape conservation schemes of the Common Agricultural Policies (CAP) of the European Union (CAP 2010). The second uncertainty is related to whether policies and practises influencing reindeer herding are aiming to transform free grazing reindeer herding or whether they are actually policies intended to support and compensate existing herding practises.

The article begins with a discussion of materials and methods and the ecosystem services framework. We then offer some background on local reindeer herding and nature conservation in Finland. Following a consideration of possible futures suggested by the four scenarios, we end by discussing and reflecting on the compatibility between nature conservation and reindeer herding and the problematics which might ensue when applying the ecosystem services framework in nature conservation.

\section{Methods}

Our material for this article derives from three previous research projects on reindeer herding and nature conservation. First, the idea of possible transformations in reindeer herding was discussed initially in 2003 during workshops of an EU-funded project "The Challenges of Modernity for Reindeer Management", but not with reference to the emergent concept of ecosystem services (cf. Heikkinen et al. 2003; Hukkinen 2008). Second, this article advances our previous research on reindeer herding and nature conservation, particularly the work we have carried out since 2008 on predator management in Finland's south-eastern reindeer herding area. We extend our arguments that the majority of predator problems faced by reindeer herding could be solved by improving compensation systems; however, wolves comprise a special case - they easily disturb the herding system as a whole and transform the very logic of traditional husbandry based on controlled free grazing (Heikkinen et al. 2011). Third, we draw on insights from a study (also carried out since 2008) examining the relationships between reindeer herding and Oulanka National Park, which is certified with a protected area network (PAN) Parks protected area/sustainable tourism ecolabel. Despite aims to create positive links between nature conservation and local development, PAN Parks certification seems to provide few benefits for reindeer herders and adds more pressure in terms of stricter conservation practises which threaten to reduce possibilities for free grazing (Sarkki et al. In press).

In this article, we draw upon the key findings of these three research projects in a scenario exercise. These scenarios are not participatory in a sense that stakeholders have taken part in creating them. Rather, we have used knowledge gained from our previous research projects, which included participatory elements. The scenario storylines are structured with the ecosystem services approach. We distinguish between policy priorities, policy practises, regulating services, provisioning and cultural services and reindeer herders' well-being. We classified our materials with reference to the above categories following the principles of content analysis to come up with the scenario storylines. 
Scenarios are a way to envision possible futures (Gallopín et al. 1997) and have become ubiquitous notably in the fields of climate change and natural resources research. The scenario is understood sometimes as being a prognosis for the future, but here we embrace a definition that scenarios are more akin to consistent and plausible narratives and storylines about how the future might unfold, as well as the existing explorations of critical uncertainties (Raskin et al. 2005). Scenarios are significant for decision makers and stakeholders concerned with formulating objectives for planning and coping with uncertain futures (Kok et al. 2007). We use scenarios as a method to stimulate critical discussion about how the future might unfold regarding reindeer herding and nature conservation in the context of ecosystem services. As such, we contribute to current discussion about how social sciences such as anthropology can engage in multidisciplinary dialogue about scenarios and storylines for a range of possible futures (e.g., Nuttall 2012). Furthermore, beyond our concern with reindeer herding, and as conservation is increasingly framed with the idea of ecosystem services, we suggest that our scenarios can provide fertile reference points for other cases. In this way, we address in part the call by the Millennium Ecosystem Assessment (MA) for advances in models that link social and ecological processes and scenarios for cultural and supporting ecosystem services (Millennium Ecosystem Assessment 2005).

We chose two key uncertainties for creating and distinguishing the four scenarios, both relating to policy choices and their relationship to reindeer herding. The first uncertainty is whether reindeer herding is viewed as a user or producer of ecosystem services, especially by decision makers (as opposed to the view of herders themselves that reindeer herding is a livelihood, as well as being a basis for local identities and cultural forms in many cases). If regarded as a 'user', there is a tendency to regulate herding more as it is perceived that reindeer herding is actually contributing to deteriorating ecosystem services and reducing biodiversity. If it is seen as a 'producer' of ecosystem services, however, reindeer herding is more likely to be supported and valued for its contribution to maintaining and nurturing biodiversity and even lauded for enhancing it. The second uncertainty relates to whether policies either aim to transform free grazing reindeer herding, for example, by top-down policy regulation, or to support existing herding practises, for example, by providing forms of compensation and subsidies.

\section{The ecosystem service approach}

\section{Policy responses to the challenge of declining ecosystem services}

The Millennium Ecosystem Assessment (Millennium Ecosystem Assessment 2005) stated that the loss of biodiversity and ecosystem services is one of the main challenges for human well-being. In addition, the Global Biodiversity Outlook (GBO) 2 set by the Convention on Biological Diversity noted that the coverage of protected areas is increasing, but that almost all other biodiversity indicators are showing negative trends. Habitats and ecosystems are deteriorating, changes in species distribution and abundance are worrying, the status of many threatened species is weakening, ecosystems are becoming more fragmented leading to lack of connectivity, and invasive alien species are taking over space from original species (GBO 2 2006). Hence, it is obvious that current conservation measures are insufficient (Chan et al. 2007). 
Given this, how are policy communities responding to the challenges posed by declining ecosystem services?

One option to halt the loss of biodiversity and ecosystem services is the creation of strong top-down policies and additional conservation measures as considered for example in Global Environmental Outlook 4's (United Nations' Environmental Program 2007) 'Policy First' scenario. This scenario considers nature-based livelihoods as users of ecosystem services whose actions should be restricted, regulated and controlled with top-down policies to maintain biodiversity and ecosystem services.

Another option to enhance ecosystem services would be to plan and implement various market-based governance instruments in order to develop incentives to maintain and also create ecosystem services. This approach, promoted for example with payments for ecosystem service (PES) schemes, assumes that by recognising and bringing ecosystem services under market regulation, resource use would become more sustainable. Here people are not only to be compensated for losses arising from nature conservation, but also incentivised for producing ecosystem services. By this way, the economic motivation is enhanced for advancing conservation willingness and thus balancing the inequalities in costs and benefits of conservation (Bruner et al. 2008; Jack et al. 2008; Sommerville et al. 2009).

Thirdly, the MA's (MA 2005) TechnoGarden scenario is based on the idea that ecosystem services can and should be generated and actively created by people, for example, by various kinds of environmental engineering approaches. Resource users would be incentivised or regulated in order to create transformations in humanenvironment interactions towards supporting and producing ecosystem services.

\section{The ecosystem service approach as an analytical tool}

The ecosystem services approach has its origins in environmental economics (Farber et al. 2002), and pays special attention to the benefits people obtain from biodiversity, ecosystems and their functions. Following the MA, there are four types of services: 1) provisioning (products obtained from ecosystems), 2) regulating (e.g. flood control; species balance), 3) cultural (non-material benefits obtained from ecosystems), and 4) supporting, which maintain all other services by for example primary production and nutrient cycling (MA 2003). These services provide the basis for human well-being (e.g. MA 2003; Carpenter et al. 2009). Preserving the ability of ecosystems to produce services can be understood to form the basis for moral, intellectual and economic imperatives for environmental governance, which should aim to build mechanisms to conserve, keep up and improve ecosystems' services. This is an anthropomorphic perspective for understanding and relating to the environment (it is beyond the scope of this article for us to engage in a critique of this, however), but nevertheless, it offers a simplistic way for policy makers to conceptualise complex interrelationships between nature and society (Figure 1).

In order to make the concept of ecosystem services more concrete, some examples of ecosystem services are provided in Table 1; they relate to forest ecosystems and were chosen because of their links to our reindeer herding case. We do not provide indicators for supporting services, but just to the other three types of services, which are 


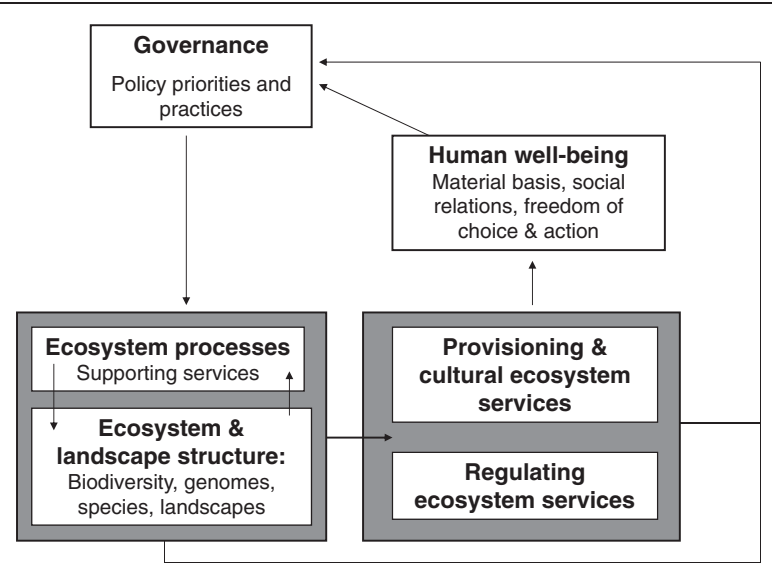

Figure 1 Ecosystem services, well-being, and governance (De Groot et al. 2002; MA 2005; Carpenter et al. 2009).

Table 1 Examples of ecosystem services (see Constanza et al. 1997; De Groot et al. 2002; MA 2005; Stenger et al. 2009) and indicators used in our case study

\begin{abstract}
Ecosystem services
Supporting:

Soil formation, primary production, nutrient cycling

Regulating

Population and keystone species control through trophic-dynamic relations, stabilising species balance.

Enhancing the reproduction of important species by suitable living and reproduction habitats.
\end{abstract}

Improving species resistance to disturbances e.g. by maintaining gene pools and viability of species populations.

Provisioning

Primary production of extractable, which are utilised in hunting, gathering, herding, berry picking etc.

\section{Sociocultural}

Environments and landscapes that support ecotourism, recreation and outdoor activities.

Existence of utilisable or otherwise valued species. Indicators used in the case study

-Balance between wolves, reindeer, wild forest reindeer, and moose.

-Estimation of the predator / wolf densities in the reindeer pastures and habitats.

The availability of prey animals for predators.

-Ability of wolves to move across borders and exchange genes with different sub-populations.

-Estimation whether the number of wolves will increase or decrease.

-Estimation of number of reindeer that ecosystem sustains.

-Estimation about the amount of lichen reindeer can utilise.

-The availability of assumingly attractive landscapes and activities within those.

-The availability of assumingly attractive species (e.g. predators, but also reindeer).

Table 2 Components of human well-being and their indicators (based on MA 2005)

\begin{tabular}{ll}
$\begin{array}{l}\text { Components of well- } \\
\text { being }\end{array}$ & Indicators used in the case study \\
\hline Freedom of choice & $\begin{array}{l}\text { Participation vs. determining the option(s) (e.g. can herders choose to continue their } \\
\text { livelihood). }\end{array}$ \\
Material basis for life & $\begin{array}{l}\text { Possibilities for income for reindeer herders. } \\
\text { Social relations }\end{array}$ \\
$\begin{array}{l}\text { Ability to continue traditional herding which is embedded with social practises; } \\
\text { possible new social relations. }\end{array}$
\end{tabular}


kinds of 'end services' and are sustained by supporting services. In addition, Table 2 outlines indicators used for assessing human well-being.

\section{Study area: Reindeer herding and nature conservation in Finland}

\section{Finnish reindeer herding}

Our case study of Finnish reindeer herding comes from the municipality of Kuusamo in the northeastern part of the Oulu province of Northern Ostrobothnia. It is a sparsely populated and largely forested area bordering Russia. In Kuusamo and neighbouring areas, reindeer herding has been a traditional livelihood since the seventeenth century when Finnish settlers adopted herding practises from indigenous Forest Sámi. Reindeer herding then spread deep into Russian Karelia until Finnish independence in 1917 and finally, the Second World War and its aftermath temporarily depopulated large parts of the Russian side of the border area. The loss of old pasture areas and the rapidly increasing industrial forestry activities forced reindeer herders to replace tree lichen pastures (which were particularly important in winter and spring) with hay feeding and reindeer farming (Kortesalmi 1996, 2008). Yet today, reindeer require access to a wide range of pastures, in which they graze, breed and survive on their own, except in those controlled herding periods during summertime when calves are earmarked, and autumn culling. Because of this free grazing tradition, the concept of semi-domesticated reindeer is often invoked to distinguish reindeer herding from intensive farming practises and wild forest reindeer dynamics. The sustainability of reindeer herding is often defined as depending on winter pastures consisting of different lichens, which are understood to be the ecologically limiting factor. Overgrazing discussions and debates about ecologically and socio-culturally sustainable reindeer densities have stigmatised discussions about reindeer for decades (Heikkinen 2006).

Contemporary reindeer herding in Finland is closely connected to the developing tourism industry sector, but also limited and placed under pressure by other forms of land use. In particular, relations with industrial forestry have been tense since the Second World War. Nature conservation is considered sometimes to be an ally of reindeer herding when calling for the protection of Finland's remaining old growth forests, which serve as important winter pastures for reindeer. On the other hand, the protection of predators such as wolves and bears during the last few decades has resulted in conflicts between reindeer herders and many nature enthusiasts. The economic situation of herding is poor in modern terms, but it still comprises one of the last traditional and in many remote areas, the only remaining occupation. Reindeer herding became especially important for small households after the heavy rationalisation of agriculture, forestry and fishing (Heikkinen 2002, 2007; Nieminen 2008).

Conservation areas often contain important pasture sites for reindeer herding. Our case study conservation area Oulanka National Park (ONP is situated mainly in the Reindeer Herding Cooperative (RHC) of Ala-Kitka (16,583 ha in ONP of total 105,702 ha, plus 2,026 ha in a strict nature conservation area), and partially in the area of the RHC of Salla (10,281 ha in ONP of total 429,327 ha) (Nieminen 2008). In Ala-Kitka, 46 owners had a total figure of 1,452 breeding reindeer, and in Salla 129 owners had 4,710 reindeer in 2009. The numbers of compensated losses of reindeer due to predation were 58 in Ala-Kitka and 66 in Salla in 2009 (Reindeer Herder's Association 2010). 
Southern RHCs have had difficulties coping with the increasing number of predators such as wolves and bears (Heikkinen et al. 2011). The overall winter pasture conditions are average or good, but most of the reindeer are artificially fed during winter and spring in order to stabilise productivity (Mikkola and Mattila 2009; Nieminen 2008).

In principle, the practise of reindeer herding in the Finnish reindeer herding area does not depend on land ownership (Reindeer Herding Act 1990/848). According to the Finnish Nature Conservation Act (1996/1096), reindeer herding is also allowed in conservation areas in a form that is regulated by its own legislation. However, the Finnish Nature Conservation Act (14§, sub item 11) allows the reserve management to regulate or prohibit herding to protect scientific research or for other designation purposes.

\section{Oulanka National Park (ONP) and linked conservation initiatives}

ONP covers an area of 28,000 ha and is situated in the sparsely populated municipalities of Kuusamo and Salla in the provinces of Northern Ostrobothnia and Lapland. The park is adjacent to the Russian border just below the Arctic Circle (Figure 2). The protection of the Oulankajoki river-Juuma area was discussed already in the 1910s1930s, but the ownership of common lands was not conclusively resolved, and local people were afraid that nature conservation would violate their rights. Thus, the proposed Oulanka and Juuma National Parks were not included in the first national park established in 1938. Their establishment came up again in the 1950s. Locals still opposed conservation; settlement was expanding fast in forest areas and economic interests were directed at forests and river rapids. After the dispute over the ownership of the Kuusamo rapids was resolved in court, the Oulankajoki riverside was left to the state to establish ONP while the Juuma area went to the local landowners and was not included within the park boundary in 1956. There were two major expansions to the park in 1982 and 1989, including the Juuma area, which raised further dispute at the local level (Ruuttula-Vasari and Juvonen, 2006). These contradictions are sometimes connected to a traditionally strong resistance to nature conservation in rural areas in Finland (and in many other countries) (Sandell 2005; Selby and Petäjistö 2008).

ONP is managed by Metsähallitus whose public administration duties include the management of protected areas (Heinonen 2007). The Natural Heritage Services of Metsähallitus, funded mostly by the state, manages Finnish national parks within the Parliamentary legislation, the Ministry of the Environment's guidelines (e.g. 2002) and Metsähallitus (e.g. 2000) own principles and management and land use plans for each park. Following the International Union for Conservation of Nature's (IUCN) protected area management categories, ONP is a category II (national park). Gilligan et al. 2005) stated that ONP had the highest management effectiveness score of any area assessed in a survey of 206 forest protected areas worldwide (Dudley et al. 2004).

ONP has become one of the most popular and well-known parks in Finland. In 2008, there were 163,000 visits to ONP, almost three times as many as in 1992. The joint goal of ONP and the adjacent Paanajärvi national park in Russia is to become the most attractive wilderness location in Europe by 2015 (Metsähallitus 2010). The aim is to achieve a competitive advantage over other national parks in Europe by combining sustainable tourism and nature conservation. According to a study conducted with use of the money generation 


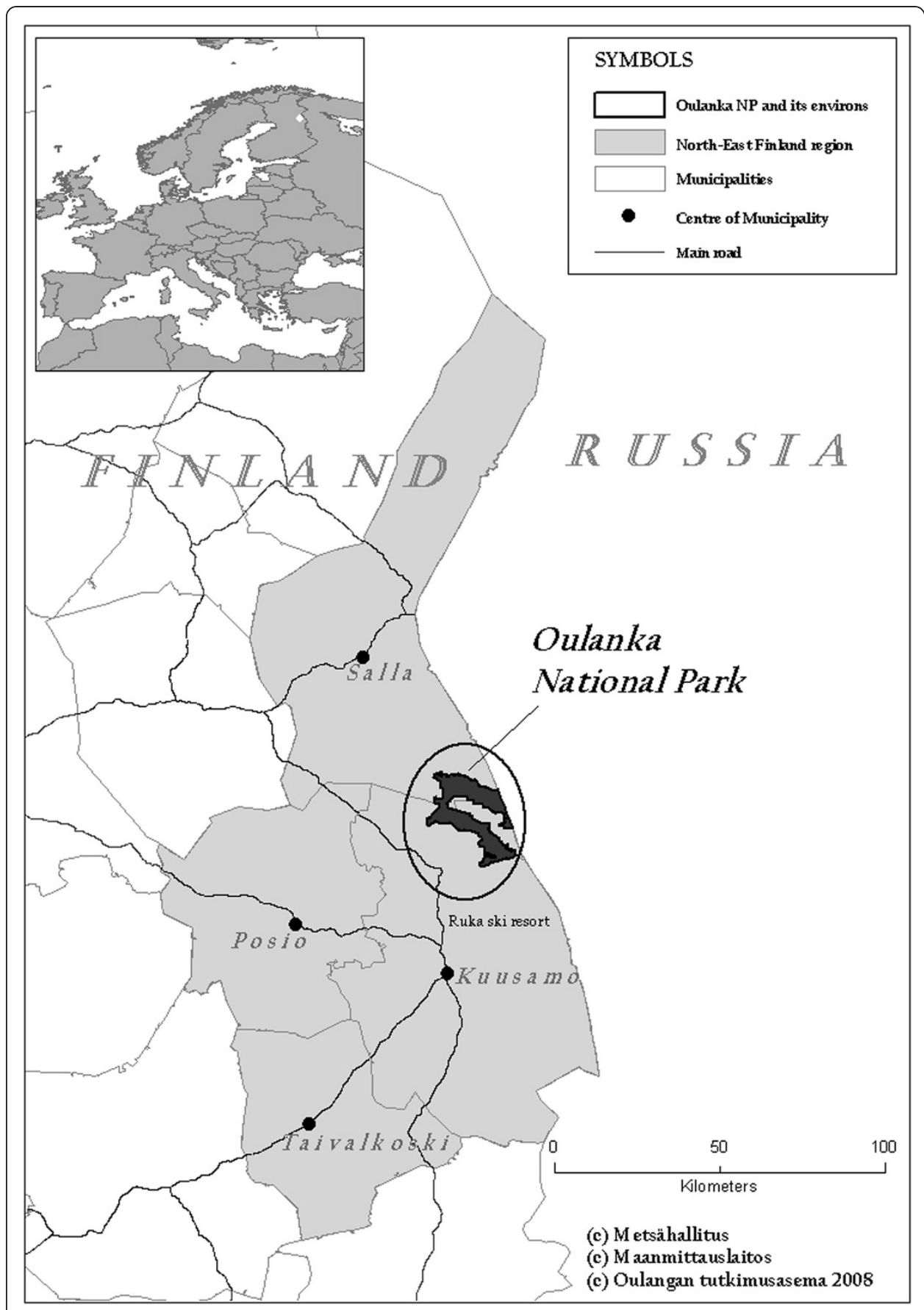

Figure 2 Koillismaa region, Kuusamo, Ruka ski resort and Oulanka National Park.

model, park visitors boosted the local economy by 14.2 million Euros in 2008 (Metsähallitus and Metla [Finnish Forest Research Institute; Helsinki, Finland] 2009). Thirty partnership companies organise recreation services in ONP, around twenty accommodation companies are located close by, and thirteen businesses have acquired the PAN Parks partner certification in the Oulanka region. 
ONP became certified as PAN Parks in 2002 (Zinke et al. 2002) and the adjacent Russian Paanajärvi National Park (104,371 ha) in 2005. Together, parks form a potential cross-border ecological corridor and hence, can be considered as a key area for advancing the idea of Fennosscandia Green Belt and, for example, viable and cross-border migratory great beast populations have a central role in this initiative (cf. Paanajärvi 2010; Metsähallitus 2010).

\section{The PAN Parks initiative}

The PAN Parks initiative provides a third-party certification system under the World Commission on Protected Areas Framework for Management Effectiveness. PAN Parks was established in 1997 by the WWF and the Dutch leisure company Molecaten (Font and Clark 2007). A park becomes certified following verification carried out by a team of independent experts in accordance with the PAN Parks (2008) five principles, each with specific criteria: natural values, habitat management, visitor management, sustainable tourism development, and tourism business partners. The minimum size of a PAN Park is 20,000 ha with a wilderness/core zone of at least 10,000 ha in its natural state, which represents the most undisturbed expanses of Europe's remaining natural landscapes. The PAN Parks criteria do not permit extractive uses in the core zone (e.g. hunting/culling, fishing or motorised transportation) even if based on traditional use. PAN Parks exerts pressure towards certain management options through the verification process, but national legislation is complied with. The PAN Parks claims to combine wilderness protection and sustainable tourism, which 'provides real benefits for the rural communities in and around the protected areas' (PAN Parks 2010). However, as PAN Parks favours a non-intervention conservation approach, it also prefers exclusion of semi-domesticated reindeer; it has claimed that any impacts of semidomesticated reindeer on ecosystems should resemble those of wild forest reindeer, which are defined as a 'natural species'. The main concern is the number of grazing reindeer within the park - a hypothetical number of wild forest reindeer is claimed to be lower than the current number of semi-domesticated reindeer (Jartti et al. 2010).

The possible benefits of PAN Parks certification for local social development via increasing tourism is still questionable, since only few tourists have used PAN Parks certification as a key motive to choose Oulanka as their travel destination (Ylimaunu 2009). However, PAN Parks may still provide better marketing networks for certified local tourism entrepreneurs. Yet, it seems that despite benefits that PAN Parks promises for local development, it benefits different local groups differently, and cannot be viewed as all-encompassing solutions to contradictions between conservation and development, not to mention dilemmas between conservation of wildlife and pastoral development (Sarkki et al. In press).

'The PAN Parks wilderness area in Oulanka is a unique example of meandering river ecosystem surrounded by untouched boreal forest near the Arctic Circle. It is the first certified piece of PAN Parks Wilderness in Finland with the ambition to protect fragments of unlogged boreal forest from intensive reindeer herding.' (PAN Parks 2010).

\section{The Green Belt initiative}

The European Green Belt initiative is coordinated by the IUCN and aims to connect national parks, reserves and transboundary protected areas along and across national 
borders. The aim is to harmonise management methods on both sides of country boundaries. The Green Belt follows the border between eastern and western Europe as it was defined (and became commonly known as the Iron Curtain) at the end of the Second World War. The reason for following this line is that these areas have remained relatively undisturbed from human interventions and have potential to become natural corridor between national states as plenty of biodiversity values are found from these border areas, including predator populations (IUCN 2010a). According to IUCN:

'The Fennoscandian and Baltic States Green Belt includes some of the last remaining old growth boreal forests, - It is mainly due to the Cold War and the consequent low economic activities, that this area remains in a nearly pristine state. - The plant and animal world is unique due to the presence of endemic animal species such as taiga reindeer, grey wolf, brown bear, wolverine, ringed seal, land-locked salmon' (IUCN 2010b).

In a sense, the creation of the European Green Belt entails an erasure of the past, an obliteration of what was an often bitter, tense and violent European political and social history, in favour of the celebration of a natural history that, while appearing to be present in areas that are last vestiges of 'natural' landscapes, is nonetheless thriving in places that have been emptied of people, or where people are now considered to be intrusive.

\section{Conservation pressures on reindeer herding Wild reindeer effects}

On several occasions, international and national conservation organisations have presented their arguments about what they see as the negative impacts of reindeer grazing on the 'natural state' of protected areas of northern Finland. For example, worries over the destruction of natural habitat by reindeer have been outlined in the IUCN evaluation report on Finnish protected areas (Gilligan et al. 2005), and IUCN's Finnish member also communicated this view in the annual reindeer herders' general meeting by stating that reindeer do not fit into national parks unless their effects on nature would resemble those of wild reindeer (Poropäivät 2005, cf. Nieminen 2008). Similar kinds of discussion about acceptable wild reindeer effects in conservation areas have focused for example, in the Malla strict nature reserve, classified as category IUCN I a in IUCN's protected area classification system, Pallas-Ylläs National Park (Jokinen 2005; Heikkinen et al. 2010), and were referred to during the PAN Parks certification process for Oulanka National Park (Sarkki et al. In press).

The wild reindeer preference is mentioned several times in ONP's verification renewal report (Stritih et al. 2007). Recently, a more modest plan was signed, according to which park management commits to reduce reindeer grazing within the park over the next few years (PAN Parks 2010). Something particularly problematic from a reindeer herding perspective, as we have found from interviewing herders, is the very low estimations of the natural wild forest reindeer densities which would not support any sort of livelihood without a considerable reformulation of the herding profession. Furthermore, motorised cross country transportation, particularly during the winter time, is an essential part of reindeer herding livelihoods today, but it is also obviously contradictory to the wild reindeer 
preferences. Similarly, different kinds of fence systems, also proposed by PAN Parks 2002 (Zinke et al. 2002), are problematic except those that are needed to control reindeer movements for culling or earmarking purposes. The leader of the Ala-Kitka reindeer herding cooperative stated in one interview: 'We have the right to free grazing and it is not reasonable for some areas to be fenced'. Furthermore, he pointed out to us that ONP has been verified as PAN Parks with the decisions of only a few people, and this new status turned reindeer, 'which have been here for ages', into a threat overnight.

\section{Viable predator populations}

The populations of what in Finland are called 'great beasts' are a key issue in many major nature conservation initiatives, for example as in the IUCN's (2010b) European Green Belt plan, and were recognised as such by PAN Parks during the ONP certification process, even though PAN Parks finally concluded that wolves in particular are problematic in ONP in accordance with current reindeer traditions. The recommendations later changed to allow for consideration of possible culling arrangements for special problem animals (e.g., Miller 2005). However, the pressures for further predator hunting limitations are on the agenda and are focused specifically on prohibiting the hunting of bears in the core zone of ONP (Miller 2005, Stritih et al. 2007; cf. Poropäivät 2005; Nieminen 2008).

One reindeer herder described an incident involving a bear inside his colleague's calving fences located near the ONP:

'He saw a bear chasing a calf and tried to disturb the bear with his all-terrain vehicle, but the bear just looked at him, took the calf and went away. The bear had killed 12 calves during the night'. Secondly, reindeer must be taken inside winter fences early because the predation risk and feeding costs have increased. A herder living next to the park said: 'There are good pastures in the park. ... I would take none of my reindeer home, but predators force me to do it, and they are increasing'.

According to our previous study, it is possible to reconcile the presence of other great beasts, such as lynx, bears and wolverines, with traditional reindeer herding - with the one exception of the wolf, which 'stirs the whole system' (Heikkinen et al. 2011). In 2008 and 2009, during our interviews with local reindeer herders and agricultural officers, who are responsible for animal-based compensations, all emphasised that reindeer kills by wolves challenges the viability of local livelihoods based on herding. For example, in the municipality of Pudasjärvi in 2007, a wolf pair killed or ripped some hundred reindeer in a period of six months and the work time of local herders changed into frustrating conservation hunting efforts and into the search for dead reindeer, as well as those reindeer that had escaped from their own pastures to those of neighbouring reindeer cooperatives (Heikkinen et al. 2011). An important suggestion made by the herders on that occasion was that the conservation hunting and predator population management costs should be fully compensated, or at least paid and arranged by those organisations that propose predator conservation. 


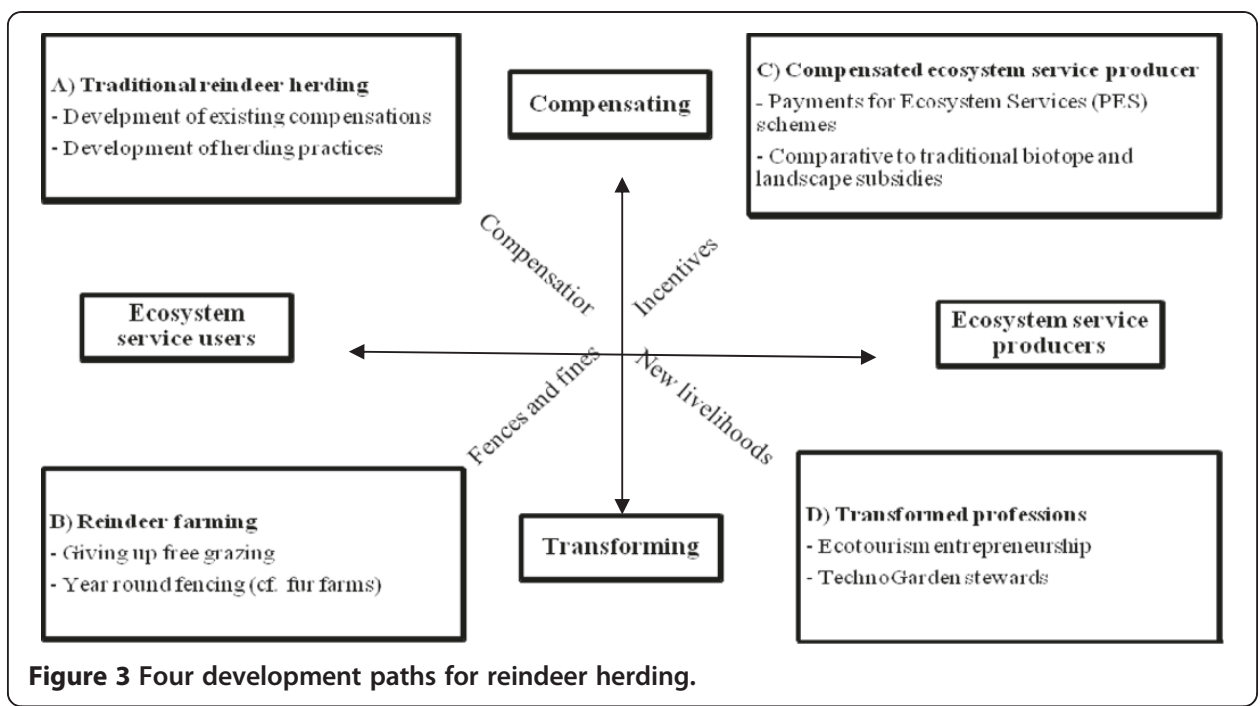

\section{Nature conservation and reindeer herding: four scenarios for the future}

We now move on to the construction of four scenarios that are based on different policy priorities related to nature conservation (Figure 3). Before each scenario, some necessary background is presented that examines existing Finnish and international developments that support the given scenario. The four scenarios on reindeer herding and nature conservation are called: A) adapting traditional herding, B) reindeer farming, C) compensated ecosystem service producer, and D) transformed professions. We structure these scenarios according to the following dimensions: 1) policy priorities, and practises 2) regulating services, 3) provisioning and cultural services, and 4) reindeer herders' well-being.

For reindeer herding, the most important policy choices will be made between enhancing compensation systems or transforming livelihood and defining herding either as a user or as a producer of ecosystem services. If defined as a user, we assume that development might follow either A) adapting current herding and compensation methods or B) increasing regulating policies to give up free grazing and transforming free grazing reindeer herding into a direction of year-round farming (cf. Heikkinen et al. 2007). In Scenario A, compensations are paid if certain management decisions, like predator conservation, have negative impacts on reindeer herding. In Scenario $\mathrm{B}$, herding is merely seen as a livelihood using and deteriorating ecosystem services and hence efforts are made to halt negative effects of herding on biodiversity and ecosystem services.

If reindeer herding will be defined as an ecosystem service producer, we assume that some innovative solutions might unfold. For example, reindeer herders could be incentivised for producing ecosystem services that would have marketing value in ecotourism and simultaneous value for ecological functions. If, following the trend on developing incentive schemes, we assume that Scenario C) certain systems of payments for ecosystem services might develop. Instead, if nature conservation policies will develop towards creating strictly interpreted 'wildernesses' and excluding traditional engagements, we assume that some more elementary transformations in reindeer herding will follow. Here we assume that transformations would particularly serve the needs of both ecotourism and ecosystem management purposes, and for herders, these could 
materialise in Scenario D) as some sort of tourism entrepreneurship or park stewardship professions.

\section{Scenario A) Adapting traditional reindeer herding}

Compensation programmes are already an approach widely used for integrating local human interests and environmental protection measures. For example, compensation has traditionally been paid to cover land owners' economic losses for certain developments, such as expropriating lands for conservation areas (Ruuttula-Vasari and Juvonen 2006). In reference to our case, the compensation system for predator damages in relation to Finnish reindeer herding is twofold. Firstly, the land-beast compensation system is based on found and proven damages to the individual reindeer herders (Sippola et al. 2005; O Moilanen, unpublished thesis; Ollila 2008). Secondly, the change in the compensation system regarding the golden eagle has been quite successful. Different Reindeer Herding Cooperatives are currently being compensated, not based on found and proven damages, but in relation to the number of nesting eagles within the cooperative as well as on the basis of the assumptions about how large a portion of the eagles' diet is based on reindeer in a given area. Currently, herders themselves are informing the Ministry about eagle nests they have located, in order to receive compensation. With terrestrial predators, there are constant accusations these are being poached by herders without licences. In Sweden, an 'area-based' compensation scheme is also applied to terrestrial predators, but it has received some criticism because the compensation is not paid directly to the herder who suffered the costs of conservation, but to the Sámi Parliament (as only Sámi are allowed to herd reindeer in Sweden, unlike in Finland), which then chooses how the money is distributed between different localities that have been affected by predators (Naskali et al. 2006; Heikkinen et al. 2011).

Policy goal and practices The policy goal is to enable the coexistence of reindeer herding and conservation priorities. Application of territory-based land-beast compensation system for reindeer herders works better than the current system based on found carcasses. In addition, electronic devices for finding carcasses and developing predator repellents are coming into use. The lost income of herders is compensated due to predation and diminished reindeer densities.

Regulating services The number of wolves and other predators has increased slightly in reindeer pastures and habitats. This has resulted in a decrease of reindeer numbers closer to the hypothetical number of wild forest reindeer, and in a slight increase of lichens. Wolves and other predators have increased because of hunting bans. Wandering great beasts strengthen the gene pool of a wider area but this serves the general targets of Green Belt and ecological corridor only partially, and the exchange of genes between Finnish and Russian wolf populations has not increased.

Provisioning and cultural services The ecosystems can sustain fewer reindeer than before because of increasing numbers of predators. However, reindeer herding communities and traditional livelihood practises still exist, even in an adapted manner. Free 
grazing reindeer herding is accepted and used in tourism marketing. Moreover, predators are utilised in marketing the tourist destination, and the predator watching industry has slightly increased.

Human well-being Reindeer herders do not have any impact on the increasing number of predators. However, improved compensation systems ensure herders' income. Tourism serves only some extra markets for expensive reindeer products. Improved compensations also improve the herders' acceptance towards predators in the area. As free grazing herding still continues in an adapted manner, the community practises and associated social relations remain. Reindeer herding traditions and vocabulary will survive and adapt, and local interaction with nature will be intense. ONP serves a rather wide variety of societal targets, but spreading predator populations create anxiety in neighbouring communities.

\section{Scenario B) Reindeer farming}

Perhaps the oldest way to resolve the tension between conservation targets and human interests is the so called 'Yellowstone model' or 'fences and fines' approach. It encompasses conservation measures by prohibitions, top-down policy control and fines, and even the very separation of human culture and society from conservation areas by fencing (Spence 1999; cf. Rytteri and Puhakka 2009). In Finnish reindeer discourses, not only the enclosure of reindeer outside certain areas, such as private forests, fields and conservation areas but also the ending of the free grazing right and the transformation of reindeer herding to farming have a long history of being discussed. Recently, the cessation of free grazing rights has been justified by references to, for example, the avoidance of traffic accidents, overgrazing problems and for nurturing larger, great beast populations (cf. Heikkinen 2002; Jokinen 2005; Rantamäki-Lahtinen 2008). Here reindeer herders are seen more strongly as users of ecosystem services, and an idea in conservation is that reindeer herders should not be allowed to deteriorate the forest floor and regional biodiversity. In addition, suggestions have been made for reintroducing wild forest reindeer to the area. There are reflections of this kind of trend in PAN Parks' recommendations to decrease the density of reindeer close to the hypothetical density of wild forest reindeer (Zinke et al. 2002, Stritih et al. 2007, PAN Parks 2010; Heikkinen et al. 2010; Sarkki et al. In press). An increase in predator numbers also results in difficulties for continuing free grazing reindeer herding. The number of wolves in Finland has also been debated between EU and Finland, as EU claimed in 2005 that Finland was violating the conservation targets of EU's habitat directive. After intense debate, the appeal was closed in 2008 when the European Commission finally stated that Finland has not threatened the sustainable level of its wolf population (Heikkinen et al. 2011; Hiedanpää and Bromley 2011). However, this debate stresses that international conservation pressures exist for increased predator conservation.

Policy goal and practices The policy goal of this scenario is that natural biodiversity is a priority. Free grazing right is ended in national parks and the remaining herders feed and protect their animals inside extensive fence systems in their private lands, 
and their livelihood is part of normal agricultural policies and subsidies. A wild forest reindeer population is reintroduced and kept up in ONP, to resemble the pristine boreal forest ecosystem.

Regulating services Predator numbers have increased but are limited because the availability of prey, the wild forest reindeer. Great beasts are intermittently present and follow the free movements of wild forests reindeer. Wandering great beasts strengthens the gene pool of the wider area and this serves the general targets of the Green Belt and ecological corridor targets. Lichens and perennial plants are abundant and sustain the hypothetical natural number of wild forest reindeer. Sparse wild forest reindeer populations have only minor effects on plant cover. All movement tracks are light, and also tourists' presence in ONP is limited.

Provisioning and cultural services As free grazing reindeer herding has ended, the ecosystems are not anymore serving to sustain semi-domesticated reindeer populations. Wild forest reindeer are not hunted. However, hay farming has increased among reindeer farmers, in order to decrease their costs of fodder. Recreational and tourism services of ONP have decreased, but the value for science and educational purposes has increased because of the presence of natural animal populations. Some of the tourists favour 'natural dynamics', but others fear unmanaged and non-hunted great beast populations.

Human well-being Traditional herding practises and communities are lost, and herders do not have the freedom to choose whether they will continue their traditional livelihood. Reindeer-related traditions, culture and language are conserved in archives and museums. Local interaction with nature is sparse, and social relations embedded in free grazing reindeer herding practises are changed. The herders' income comes from reindeer farming, which is subsidised like sheep farming, for example. Tourism, park management and remaining reindeer farming are separate engagements. Particularly problematic for neighbouring areas are the effects on wild animals followed by great beasts and the fluctuating wild animal populations. Also neighbouring Reindeer Herding Cooperatives increasingly give up free grazing.

\section{Scenario C) Compensated ecosystem service producer with PES schemes}

The third conservation trend develops in direct connection to the ecosystem services approach: different PES have been developed for enhancing ecosystem service production (Jack et al. 2008; Sommerville et al. 2009), and PES can be used to balance the inequalities in distributing costs and benefits of proposed conservation measures (Bruner et al. 2008). In short, PES systems are built to make conservation economically and locally attractive (cf. Daily and Matson 2008; Pejchar et al. 2007). A combined approach of conservation and development may offer simultaneous environmental and economic advantages locally by incentivising local engagements towards park keeping, conservation hunting, meadow mowing or sheep grazing services. In fact, the EU CAP subsidies and other agro-environmental schemes of the EU for keeping up traditional landscapes and biotopes aleady follow this logic (CAP 2010, 2011; Birge 
and Fred 2011 unpublished work). Regarding other sectors in Finland, Finnish forestry in northern state lands is increasingly including 'neoliberal' elements, and marketbased governance seems often to over-run previously state-based decision making (Sarkki and Rönkä 2012). In addition, a PES scheme called 'nature values trade' regarding private forests has been a rather successful experiment in efforts to combine forest ownership and nature conservation (Paloniemi and Vilja 2009). A key difference with the two previous scenarios (A and $\mathrm{B}$ ) is that here reindeer herders are viewed as producers of ecosystem services and are incentivised for doing so.

Policy goal and practices The policy goal of this scenario is to promote synergies between business and conservation. Biodiversity and local socio-cultural priorities are guaranteed with a wide variety of ecolabels, which are utilised in marketing 'sustainable nature tourism'. Reindeer herders are supported for producing certain ecosystem services. Particularly, PES are paid for creating wild reindeer simulating grazing effects and for allowing predation on reindeer. Herders are incentivised for keeping up some reindeer population year round inside ONP for predators and tourists. PES are paid also for conservation hunting and maintaining stable great beast populations and preventing their spread to the neighbouring areas.

Regulating services Carnivore-herbivore natural dynamics are working partially, but population fluctuations and movements are stabilised by human interventions (e.g. by conservation hunting and controlled number and movements of reindeer). Large predators have only a slight effect on surrounding areas and hence only partially support the general targets of Green Belt and ecological corridor ideologies. There is no exchange of genes between predator populations, because predator movements are highly managed. However, some new genes may be imported from other populations. Semi-domesticated reindeer simulate wild reindeer in the ONP ecosystem, and thus the number of reindeer is kept quite small within the park.

Provisioning and cultural services As reindeer herding is centred on substituting wild forest reindeer, especially within the park, the number of animals decreases. The production of meat and compensation form the basis of reindeer herder incomes. Predators are present and utilised in the tourism industry (e.g. such as bear watching). Predator-watching enterprises pay compensation to herders. Ecolabel boosted tourism creates local income. The value of reindeer products is very low and serves tourism directly, but mostly in marketing. Tourism routes are clear and build to sustain rather a great number of visitors.

Human well-being Nature-based tourism combined with compensated ecosystem service production guarantees higher income for local herding communities, but parts of the traditional herding-related practices have disappeared. Herders can choose if they take part in incentivised practises, but those reindeer herders who take part in incentivised ecosystem service production have better income possibilities than those who continue with more traditional herding. Part of the reindeer-related cultural and linguistic traits will disappear, but local interaction with nature is widespread and 
regular. Herding is still a separate profession, but amalgamated partially to naturebased tourism and park management activities.

\section{Scenario D) Transformed professions}

Here reindeer herders have two opportunities for transforming their profession: herders could become so called 'ecosystem stewards' or transform their livelihoods into ecotourism entrepreneurship. Ecotourism has been recognised as one of the most important ecosystem services provided by protected areas (Kettunen et al. 2009). Reindeer herders are already assumed and encouraged to benefit from increasing ecotourism through transformations from 'extractive' livelihoods to ecotourism-oriented businesses (Stritih et al. 2007). Local park stewardship is another potential for the future, also in line with the idea of an environmental engineering approach put forward by MAs (2005) TechnoGarden scenario. Ecosystem stewards are those whose actions modify the quantity or quality of ecosystem services available to environmental service beneficiaries. Ecosystem stewards are recognised by society as having the right to interact with an ecosystem, provided they accept limitations on those rights and obligations to maintain the ecosystem' (Swallow et al. 2009). In short, the local educated stewards are paid for producing the services, and their salaries will compensate the lost income possibilities from traditional livelihoods and changes in socio-cultural practises. The role of locals as ecosystem stewards has been proposed for example in relation to hunting of predators (Holsman 2000). It has been also suggested that wolves and other predators could keep the herbivore dynamics stable within national parks (Brown 2010). It would be then the task of human stewards to regulate the predator populations.

Policy goal and practices The policy goal includes production of ecosystem services by widespread environmental engineering. Semi-domesticated reindeer are used as substitutes for wild forest reindeer, and managed as prey for predators. Biodiversityconcentrated ecolabels cease free grazing rights inside the ONP, and former herders are encouraged and subsidised for ecotourism-related businesses or for taking jobs as Park stewards, and become normal paid employees of Park management. Adoption of 'zoo-like' management practises and widespread marketing of 'the Wilderness Experience Park' are taking place.

Regulating services ONP is managed to support and conserve a high variety of endangered species and habitats inside the park. It serves other ecosystems mostly as a gene bank, and genetic exchange between Finnish and Russian wolf populations is ensured by increasing collaboration in transboundary Oulanka-Paanajärvi Park. For supporting the highest possible variety of ecosystem functions, ONP's nature is managed in a zoo-like manner. For example, animal populations are highly managed, their movements are controlled by fencing, and populations are kept stable by conservation hunting and regular reintroductions.

Provisioning and cultural services There would not be any reindeer meat production for human consumption, as in the previous scenarios, and economic values are created 
only through ecotourism. High management level makes high tourism numbers and new programmes possible. For example, ecotourism entrepreneurs sell predatorwatching programmes. Park stewards control, manage and create habitats inside ONP and keep populations stable and control animal movements outside of the park. Park stewards can also make conservation hunting part of tourism business, by involving customers in arranged activities. Tourism infrastructures are hidden and routes lead to various wilderness spotting places.

Human well-being Local traditional livelihoods are lost and newly transformed professional roles guarantee high local income only for those who are able to adjust to them. Those who are engaged in these transformed professional roles interact with nature intensively and are part of the process of creating a 'Wilderness Experience Park' either as ecosystem stewards or ecotourism entrepreneurs.

Table 3 Summary of tentative trade-offs related to scenarios

\begin{tabular}{|c|c|}
\hline Scenario A) Traditional reindeer herding & $\begin{array}{l}\text { Scenario C) Compensated ecosystem service } \\
\text { producer }\end{array}$ \\
\hline Gainers: & Gainers: \\
\hline -Pastoralist's home economics & $\begin{array}{l}\text {-Manageability of predator and semi-domesticated } \\
\text { reindeer }\end{array}$ \\
\hline -Predator populations (easy prey) & -Continuing local herding communities \\
\hline \multirow{2}{*}{$\begin{array}{l}\text {-Semi-domesticated reindeer's instincts and survivability } \\
\text { (continuous predation pressure) }\end{array}$} & -Incentivized motive for reindeer management \\
\hline & -Natural grazing pressure simulations \\
\hline Losers: & Losers: \\
\hline -State (high compensations costs) & -State (high costs of incentives) \\
\hline -Traditional food for humans production motive & $\begin{array}{l}\text {-Predator watching enterprises (payments for } \\
\text { herders for increasing predation) }\end{array}$ \\
\hline $\begin{array}{l}\text {-Motive for reindeer management (changes to searching } \\
\text { of killed reindeer) }\end{array}$ & -Traditional food for humans production motive \\
\hline -Predators hunting instinct and skills & -Natural dynamics of hunting pressure \\
\hline Scenario B) Reindeer farming & Scenario D) Transformed professions \\
\hline Gainers: & Gainers: \\
\hline -Traditional food for humans production motive & $\begin{array}{l}\text {-Manageability, stability and commodification of } \\
\text { local environment }\end{array}$ \\
\hline \multirow{4}{*}{$\begin{array}{l}\text {-Agricultural investment economy (rising costs of } \\
\text { production, but steady harvest) }\end{array}$} & -Wild forest reindeer population \\
\hline & $\begin{array}{l}\text {-Local and semi-local conformists (educated, } \\
\text { probably young opportunists) }\end{array}$ \\
\hline & -Tourism \\
\hline & -Municipal economies \\
\hline Losers: & Losers: \\
\hline -Domesticated reindeer meat quality & $\begin{array}{l}\text {-Traditionalists (local conservatives not willing for } \\
\text { modern occupations) }\end{array}$ \\
\hline -Domesticated reindeer's instincts and survivability & -Nature's uncontrolled dynamics \\
\hline -Predator populations (loss of easy prey) & -Traditional local culture and communities \\
\hline $\begin{array}{l}\text {-Reindeer herders' socio-cultural traditions and freedom of } \\
\text { choice regarding their livelihood. }\end{array}$ & \\
\hline
\end{tabular}




\section{Conclusions: uncertainties in the ecosystem service approach and scenarios}

Our scenarios show that there are many compatibilities as well as incompatibilities between pastoralism and nature conservation, and there are multiple ways by which the ecosystem service framework could be applied (Table 3). We conclude that even though seeing reindeer herders as producers of ecosystem services may offer some innovative solutions to dilemmas between pastoralism and conservation, there are also various uncertainties related to the ecosystem service approach. The uncertainties involved are firstly related to a number of questions, such as: in what ways can human-created services substitute 'natural' ecosystem functions? What degree of ecological complexity is needed for service production? What are the limits and indicators of successful environmental engineering in large areas (see MA 2005)? It seems evident that even rather light environmental engineering does change the behaviour of wildlife, but how and to what extent does this lead to genetic variation and change?

The second set of uncertainties is related to more general assumptions about ecotourism and cultural services. Tourism could benefit from predators, since predatorwatching is an increasingly significant business in Finland, but would the engineered 'zoo-like' parks satisfy tourists' quest for a wilderness experience? Or would the increased number of predators create fear in tourists?

Thirdly, despite the anthropocentric dimension of the ecosystem service concept, the question remains of who actually benefits from the ecosystem service production approach in nature conservation. There is a relative lack of research on the interrelations between ecosystem services production and human well-being (Carpenter et al. 2009), and the link between local community well-being and ecosystem service production can be, and often is, negative. In addition, it has been argued that the concept of ecosystem services in fact blinds us from understanding ecological, economic and social complexities and interrelationships (Norgaard 2010). This blinding might take place, for example, when applying ecosystem service-based incentives to local resource governance. Can these monetary measures also compensate for the social and cultural changes taking place with the new governance tools? Will pastoralists accept the production of livestock mainly for predators? It seems that many conservation organisations have adopted popular scientific concepts and use them as justification for conservation targets. The danger is that the ecosystem service approach remains as distant to local well-being and experience as have the earlier 'fences and fines' conservation approaches or species conservation agendas. Hence, pastoral communities should be engaged in the discussions over nature conservation, so as to establish proper links between ecosystem services and community well-being.

The third uncertainty is related to PES schemes. It has been documented that PES schemes may produce negative impacts on local livelihoods and that their effects are more complex than simple assumptions of local benefits (e.g. Grieg-Gran et al. 2005). In the light of our scenario exercise, PES schemes may in fact produce new kinds of inequalities at the local level between those who are able and willing to transform their practises guided by such schemes, and those who will not or cannot transform their practises. Thus, even though PES schemes seem to be promising for herders, in comparison to other scenarios, PES schemes may generate new kind of inequalities and contribute to social tensions at the local level. 
The discussions between pastoralists and conservation agencies could be aided by scenario exercises, such as the one presented in this article. Participatory workshops could be arranged by researchers using scenarios on the relationships between pastoralists and nature conservation agencies, as a starting point for discussions. In this way, local values, understandings and everyday practises could be evaluated in relation to conservation targets. Whatever the final policy solutions will encompass in future, their success will be bound to and legitimated by local commitment and acceptance. Without this, what are intended as policy practises might end up as mere policy exercises.

\section{Competing interests}

The authors declare that they have no competing interests.

\section{Authors' contributions}

Empirical studies for this article were conducted primarily by HH and SS. HH focused more on predator and reindeer problematics while SS studied the relationships between reindeer herding and Oulanka National Park. Analysis of the research material and developing the scenario exercise was a joint intellectual effort of $\mathrm{HH}$, SS and MN. Actual article writing was equally performed by $\mathrm{HH}$ and $\mathrm{SS}$, and $\mathrm{MN}$ provided international expertise and points of comparison for the Finnish case as well as editorial help. All authors read and approved the final manuscript.

\section{Acknowledgments}

We like to thank reviewers and editors for constructive comments. This study was conducted as part of the Finland Distinguished Professor (FiDiPro) programme 'Human-environment relations in the north: resource development, climate change and resilience' funded by the Academy of Finland and based at the Thule Institute, University of Oulu, Finland and the Department of Anthropology, University of Alberta, Canada. Some funding was also received from the Emil Aaltonen Foundation.

\section{Author details}

${ }^{1}$ Faculty of Humanities, University of Oulu, PO Box 100090014, Oulu, Finland. ${ }^{2}$ Thule Institute, University of Oulu, PO Box 730090014, Oulu, Finland. ${ }^{3}$ Department of Anthropology, University of Alberta 13-15 HM Tory Building, Edmonton, Alberta $66 \mathrm{H} 2 \mathrm{H} 4$, Canada.

Received: 17 October 2011 Accepted: 27 February 2012

Published: 28 September 2012

\section{References}

Birge, T, and M Fred. 2011. (Unpublished). Using Social-Ecological Inventory to Identify Ecosystem Services and Stewards of Traditional Rural Biotopes in SW Finland. http://www.bioecon.ucl.ac.uk/12th_2010/Birge.pdf. Accessed 29 September 2011

Bisi, J, S Kurki, M Svensberg, and T Liukkonen. 2007. Human dimensions of wolf (Canis lupus) conflicts in Finland. European Journal of Wildlife Research 53(4): 304-314.

Brown, M. 2010. Ranger Wolf: predators pushed as park stewards. The Seattle Times. 7 February 2010. http://seattletimes nwsource.com/htm//localnews/2011008041_apmtwolfnation1 stldwritethru.html. Accessed 29 September 2011.

Bruner, A, R Naidoo, and A Balmford. 2008. Review of the costs of conservation and priorities for action. http://ec. europa.eu/environment/nature/biodiversity/economics/teeb_en.htm. Accessed 15 February 2010.

Buller, H. 2008. Safe from the wolf: biosecurity, biodiversity, and competing philosophies of nature. Environmental Planning A 40: 1583-1597.

CAP. 2010. Agriculture and rural development. http://ec.europa.eu/agriculture/envir/. Accessed 2 March 2010.

CAP. 2011. Agriculture and rural development: taking care of countryside. http://ec.europa.eu/agriculture/capexplained/ countryside/index_en.htm. Accessed 29 September 2011.

Carpenter, S, H Mooney, J Agard, D Capistrano, R DeFries, S Díaz, T Dietz, A Duraiappah, A Oteng-Yeboah, H Pereira, C Perrings, W Reid, J Sarukhan, R Scholes, and A Whyte. 2009. Science for managing ecosystem services: beyond the Millennium Ecosystem Assessment. Proceedings of the National Academy of Sciences of the United States of America 106(5): 1305-1312.

Chan, K, R Pringle, J Ranganathan, C Boggs, Y Chang, P Ehrlich, P Haff, N Heller, K Al-Khafaji, and D Macmynowski. 2007. When agendas collide: human welfare and biological conservation. Conservation Biology 21(1): 590-68.

Convention on Biological Diversity (CBD). 2010. Convention on biological diversity: revising and updating the CBD strategic plan, post-2010. http://www.cbd.int/sp/sp2010+/. Accessed 15 February 2010.

Costanza, R, R d/Arge, R de Groot, S Farber, M Grasso, B Hannon, S Naeem, K Limburg, J Paruelo, RV O’Neill, RG Raskin, P Sutton, and $\mathrm{M}$ van den Belt. 1997. The value of the world's ecosystem senvices and natural capital. Nature 387: 253-260.

Countdown 2010. Save biodiversity, move from words to action. IUCN. http://www.countdown2010.net/biodiversity. Accessed 28 September 2011.

Daily, G. 1997. Nature's services: societal dependence on natural ecosystems. Washington: Island Press.

Daily, G, and P Matson. 2008. Ecosystem services: from theory to implementation. Proceedings of the National Academy of Sciences of the United States of America 105(28): 9455-9456.

De Groot, S, M Wilson, and R Boumans. 2002. A typology for the classification, description and valuation of ecosystem functions, goods and services. Ecological Economics 41(3): 393-408. 
Dudley, N, A Belokurov, O Borodin, L Higgins-Zogib, M Hockings, L Lacerda, and S Stulton. 2004. Are protected areas working? An analysis of forest protected areas by WWF. Gland: WWF International.

2009. U Nature \& Biodiversity Partnerships. http///ec.europa.eu/environment/nature/partnerships/. Accessed 17 February 2010.

Farber, S, R Costanza, and M Wilson. 2002. Economic and ecological concepts for valuing ecosystem services. Ecological Economics 41(3): 375-392.

Finnish Nature Conservation Act 1996/1096.

Font, X, and S Clark. 2007. Certification of protected areas: the case of PAN Parks in Europe. In Quality control and certification in ecotourism, ed. R Black and A Crabtree, 299-315. Wallingford: CABI.

Gallopín, G, A Hammond, P Raskin, and R Swart. 1997. Branch points: global scenarios and human choice. Stockholm, Sweden: Stockholm Environment Institute.

GBO 2. 2006. Summary of the Second Global Biodiversity Outlook. Convention on biological diversity. http://www.cbd. int/gbo/. Accessed 17 February 2010.

Gilligan, B, N Dudley, A de Tejada, and H Toivonen. 2005. Management effectiveness evaluation of Finland's protected areas. Nature Protection Publications of Metsähallitus, Series A 147. http://www.metsa.fi/MEE. Accessed 11 January 2008.

Grieg-Gran, M, I Porras, and S Wunder. 2005. How can market mechanisms for forest environmental services help the poor? Preliminary lessons from Latin America. World Development 33(9): 1511-1527.

Heikkinen, H. 2002. Sopeutumisen mallit — Poronhoidon adaptaatio jälkiteolliseen toimintaympäristöön Suomen läntisellä poronhoitoalueella 1980-2000. [Integrating models adaptation of reindeer herding post-industrial environment in the western Finnish reindeer herding area 1980-2000] Hakapaino: PhD Dissertation University of Oulu. Finnish Literature Society.

Heikkinen, H, J Hukkinen, O Jääskö, A Laakso, L Müller-Wille, S Nevalainen, K Raitio, and N West. 2003. Poronhoidon tulevaisuus. Raportti EU: RENMAN-hank keen Kittling työpajasta 13-15 August 2003. [The future of reindeer management: report of the EU RENMAN Project Workshop in Kittilä 13-15 August 2003] Technology, Society, Environment July 2003. Espoo: Helsinki University of Technology Laboratory of Environmental Protection.

Heikkinen, H. 2006. Neo-entrepreneurship as an adaptation model of reindeer herding in Finland. Nomadic Peoples 10 (2): 187-208.

Heikkinen, H, S Lakomäki, and J Baldridge. 2007. The dimensions of sustainability and the neo-entrepreneurial adaptation strategies in reindeer herding in Finland. Journal of Ecological Anthropology 11: 25-42.

Heikkinen, H, O Moilanen, M Nuttall, and S Sarkki. 2011. Managing predators, managing reindeer: contested conceptions of predator policies in Finland's southeast reindeer herding area. Polar Record 47(242): 218-230.

Heikkinen, H, S Sarkki, M Jokinen, and D Fornander. 2010. Global area conservation ideals versus the local realities of Reindeer Herding in Northernmost Finland. International Journal of Business and Globalisation 4(2): 110-130.

Heinonen, M. 2007. State of the parks in Finland: Finnish protected areas and their management from 2000 to 2005. Nature Protection Publications of Metsähallitus A 170. Vantaa: Metsähallitus. Available at: http://www.metsa.fi/ SIVUSTOT/METSA/EN/NATURALHERITAGE/PROTECTEDAREAS/STATEOFTHEPARKSREPORTING/Sivut/ StateoftheParksReporting.aspx. Accessed 17 August 2012.

Hiedanpää, J, and D Bromley. 2011. The harmonization game: reasons and rules in European biodiversity policy. Environmental Policy and Governance 21(2): 99-111.

Hirschnitz-Garbers, M, and S Stoll-Kleemann. 2011. Opportunities and barriers in the implementation of protected area management: a qualitative meta-analysis of case studies from European protected areas. Geographical Journal 177 (4): $321-334$.

Holsman, R. 2000. Goodwill hunting? Exploring the role of hunters as ecosystem stewards. Wildlife Society Bulletin 28 (4): 808-816.

Hukkinen, J. 2008. Sustainability networks: cognitive tools for expert collaboration in social-ecological systems. London: Routledge.

IUCN. 2010a. Broadening boundaries — naturally, the Green Belt of Fennoscandia. http://www.iucn.org/knowledge/ news/?4898/Broadening-boundaries — naturally. 11 March 2010. Accessed 18 August 2011.

IUCN. 2010b. The European Green Belt Initiative. http://europeangreenbelt.org/001.route_fs.html. Accessed 24 February 2010.

Jack, B, C Kousky, and K Sims. 2008. Designing payments for ecosystem services: lessons from previous experience with incentive-based mechanisms. Proceedings of the National Academy of Sciences of the United States of America 105(28): 9465-9470.

Jartti, L, K Lahti, and M Hovi. 2010. Jartti et al. wilderness zone program for Oulanka National Park 2010. Jartti et al.

Jokinen, M. 2005. Poronhoidon ja suojelun vaikutukset Mallan luonnonpuistossa. METLA Kolari, 941. [Reindeer herding and protection effects Malla Strict Nature Reserve] Metsäntutkimuslaitoksen tiedonantoja. Metla Kolari.

Kettunen, M, S Bassi, S Gantioler, and P ten Brink. 2009. Assessing socio-economic benefits of Natura 2000 - a toolkit for practitioners. Brussels, Belgium: Institute for European Environmental Policy.

Kok, K, R Biggs, and M Zurek. 2007. Methods for developing multiscale participatory scenarios: insights from southern Africa and Europe. Ecology and Society 13(1): 8.

Kortesalmi, J. 2008. Poronhoidon synty ja kehitys Suomessa. [Reindeer herding the birth and development in Finland] Helsinki: SKS,

Kortesalmi, J. 1996. Pohjois-Vienan Poronhoito. Talonpoikien poronhoidon alue, ominaislaatu, ikä, alkuperä ja kehityslinjat vuoteen 1922. [North of the white reindeer husbandry: the peasants of reindeer herding area, character, age, origin and trends to 1922] Helsinki: Suomen muinaismuistoyhdistys [Doctoral Dissertation. University of Helsinki, Finland: The Finnish Antiquarian Society.

K Mikkola and E Mattila. 2009. Poronhoitoalueen etelä-ja keskiosien talvilaitumet. Tila paliskunnissa 2000-luvun alkuvuosina ja eräiden ravintokasvien esiintymisrunsauden muutokset merkkipiireissä 1970-luvulta lähtien. [The reindeer herding area in southern and central parts of the winter pastures. Status herding districts the 2000s and the early years of some food plants esiintymisrunsauden changes herald circles since the 1970s.], 57. Finland: Metlan työraportteja [Finland: Metla Working Papers/Working Papers of the Finnish Forest Research Institute] 115 . 
Metsähallitus. 2000. The principles of protected area management in Finland. Guidelines on the aims, function and management of state-owned protected areas. Nature Protection Publications of the Finnish Forest and Park Service B 54. http://julkaisut.metsa.fi/julkaisut/pdf/luo/b054.pdf. Accessed 10 September 2008.

Metsähallitus. 2010. Life Nature Projects and Structural Fund Projects. http://www.metsa.fi/sivustot/metsa/en/Projects/. Accessed 2 March 2010.

Metsähallitus and Metla. 2009. Kansallispuistojen ja retkeilyalueiden kävijöiden rahankäytön paikallistaloudelliset vaikutukset. [National parks and camping areas important to the local economy] Metsähallitus 2009. http://www. metsa.fi/sivustot/metsa/fi/Eraasiatjaretkeily_Nirkistyskaytonsuunnittelu/suojelualueidenmerkityspaikallistaloudelle/ Sivut/Kansallispuistoihinsijoitetutrahatpalautuvatmonikertaisina.aspx. Accessed 30 November 2009.

Millennium Ecosystem Assessment. 2003. Ecosystems and human well-being: a framework for assessment. Washington: Island Press.

Millennium Ecosystem Assessment. 2005. Ecosystems and human well-being: synthesis. Washington: Island Press.

Miller, G. 2005. PAN Parks 2005: PAN Parks Verification. Oulanka National Park, Finland. Monitoring Report. PAN Parks.

Ministry of the Environment. 2002. Ohjelma luonnon virkistyskäytön ja luontomatkailun kehittämiseksi. The Finnish Environment 535. [SY535 Program of the recreational use and nature-based tourism development]. Finland: Finnish Environment Institute.

Naskali, A, H Juha, and S Leila. 2006. Biologinen monimuotoisuus talouskysymyksenä. Suomen ympäristö 48. [SY48/2006 Biodiversity economics of the Finnish government] Nature, 142.

Newmark, W, D Manyanza, D-G Gamassa, and H Sariko. 1994. The conflict between wildlife and local people living adjacent to protected areas in Tanzania: human density as a predictor source. Conservation Biology 8(1): 249-255.

Nieminen, M. 2008. Luonnonsuojelualueiden merkitys ja käyttö Suomen poronhoidossa Loppuraportti 2008. [Importance of protected areas and the use of Finnish reindeer herding - Final Report, 2008] Porontutkimusasema, Kaamanen: Riista - ja kalatalouden tutkimuslaitos [Game and Fisheries Research Institute, Reindeer Research Station, Kaamanen].

Norgaard, R. 2010. Ecosystem services: From eye-opening metaphor to complexity blinder. Ecological Economics 69: 1219-1227.

Nuttall, M. 2012. Tipping points and the human world: living with change and thinking about the future. Ambio 41(1): 96-105.

Ollila, T. 2008. Maakotkaraportti 2007. Metsähallitus. [Report on Golden Eagles 2007]. http://wwwz.metsa.fi/sivustot/ metsa/SiteAttachments/Maakotkaraportti2007.pdf. Accessed 12 March 2012. (Unofficial translation).

Paanajärvi. 2010. The Paanajärvi National Park. http://parks.karelia.ru/paanajarvi/. Accessed 2 March 2010.

Paloniemi, R, and V Vilja. 2009. Changing ecological and cultural states and preferences of nature conservation policy: The case of nature values trade in south-western Finland. Journal of Rural Studies 25(1): 87-97.

PAN Parks. 2008. Verification Manual. Principles and criteria 1-3, 4, and 5 January 2008. Endorsed by the Supervisory Board. http://www.panparks.org/learn/apply_for_verification/principles_and_criteria. Accessed June 112010.

PAN Parks. 2010. PAN Parks concept, case studies and certified national parks. http://www.panparks.org/. Accessed 24 February 2010.

Pejchar, L, P Morgan, M Caldwell, C Palmer, and G Daily. 2007. Evaluating the potential for conservation development: biophysical, economic, and institutional perspectives. Conservation Biology 21(1): 69-78.

Poropäivät. 2005. Kooste Poropäivien esitelmätiivistelmistä Kaamanen 28.-29.4.2005 [Abstracts of presentations in reindeer husbandry days 28-29 April 2005 in Kaamanen]. Riistantutkimuksen tiedote 199: 1-35. Helsinki, 28 April 2005. (Unofficial translation).

Rantamäki-Lahtinen, L. 2008. Porotalouden taloudelliset menestystekijät. [Reindeer husbandry economic success factors] MTT selvityksiä 156. [MTT Research Studies] Agrifood. Finland: MTT Agrifood Research Finland.

Raskin, P, F Monks, T Ribeiro, D van Vuuren, and M Zurek. 2005. Global scenarios in historical perspective. In Ecosystems and human wellbeing: scenarios. Volume 2: findings of the scenarios working group of the Millennium Ecosystem Assessment, ed. SR Carpenter, PL Pingali, EM Bennett, and MB Zurek, 35-44. Washington: Island Press.

Reindeer Herder's Association. 2010. Reindeer Herder's Association. Annual statistics. Rovaniemi. http://www.paliskunnat. fi. Accessed 9 March 2010

Ruuttula-Vasari, A, and S-K Juvonen. 2006. Oulanka - kuohujen keskeltä kansallispuistoksi. [Oulankajoki: the foam in the middle as a national park] Metsähallitus: Pohjanmaan luontopalvelut. Metsähallitus: Ostrobothnia Natural Heritage Services.

Rytteri, T, and R Puhakka. 2009. Formation of Finland's national parks as a political issue. Ethics, Place and Environment 12(1): $91-106$

Sandell, K. 2005. Access, tourism and democracy: a conceptual framework and the non-establishment of a proposed national park in Sweden. Scandinavian Journal of Hospitality and Tourism 5(1): 63-75.

Sandström, C, J Pelllikka, O Ratamäki, and A Sandec. 2009. Management of large carnivores in Fennoscandia: new patterns of regional participation. Human Dimensions of Wildlife: An International Journal 14(1): 37-50.

Selby, A, and L Petäjistö. 2008. Residents' adjustments to adjacent national parks: a place-bound structuration perspective. Working Papers of the Finnish Forest Research Institute 90. http://www.metla.fi/julkaisut/ workingpapers/2008/mwp090.htm. Accessed 15 September 2008.

Sarkki, S. 2011. The site strikes back: participation and forest governance in northern Finland. PhD thesis. Finland: Thule Institute and Discipline of Anthropology, University of Oulu.

Sarkki, S, HI Heikkinen, and R Puhakka. In press. Boundary organizations between conservation and development: Insights from Oulanka national park. Finland: World Review of Entrepreneurship, Management and Sustainable Development.

Sarkki, S, and AR Rönkä. 2012. Neoliberalisations in Finnish forestry. Forest Policy and Economics 15: 152-159.

Sippola, A-L, H Norberg, M Renko, K Suopajärvi, and T Sutinen. 2005. Petovahinkojen sosioekonominen merkitys porotaloudelle Suomessa - loppuraportti. [Socio-economic importance of predator damages for reindeer husbandry in Finland: Final Report] University of Lapland: Arctic Centre Reports 2005: 44. (Unofficial translation).

Skogen, K, I Mauz, and O Krange. 2008. Cry wolf! Narratives of wolf recovery in France and Norway. Rural Sociology 73 (1): 105-133. 
Spence, MD. 1999. Dispossessing the wilderness: Indian removal and the making of the national parks. Cary: Oxford University Press.

Sommerville, M, J Jones, and E Milner-Gulland. 2009. A revised conceptual framework for payments for environmental services. Ecology and Society 14(2): 34.

Stenger, A, P Harou, and S Navrud. 2009. Valuing environmental goods and services derived from the forests. Journal of Forest and Economics 15(1-2): 1-14.

Stritih, J, F Mari, and H Karjalainen. 2007. PAN Parks 2007: PAN Parks verification. Oulanka National Park, Finland. Renewal verification report. Principles and Criteria 1-3 and 4-5. PAN Parks.

Swallow, B, M Kallesoe, U Iftikhar, M van Noordwijk, C Bracer, S Scherr, K Raju, S Poats, A Kumar, O Duraiappah, B Chieng, H Mallee, and R Rumley. 2009. Compensation and rewards for environmental services in the developing world: framing pan-tropical analysis and comparison. Ecology and Society 14(2): 26.

Thompson, J. 1993. Addressing the human dimensions of wolf reintroduction: an example using estimates of livestock depredation and costs of compensation. Society and Natural Resources 6: 165-179.

United Nations' Environmental Program (UNEP). 2007. Global Environment Outlook 4. Environment for development. UNEP, Nairobi. http://www.unep.org/geo/geo4/. Accessed 15 February 2010.

WWF. 2010. Science: payment for ecosystem services. http://www.worldwildlife.org/science/projects/ecosystemserv/ item1987.html?linklocation=topnavdropdownmenu. Accessed 15 February 2010

Ylimaunu, T. 2009. Matkailun ympäristösertifiointien tunnettuus ja merkitys luontomatkailijoille: esimerkkinä Oulangan kansallispuisto ja PAN Parks - sertifikaatti. [Environmental certification of tourism awareness and the importance of nature tourists: the example of Oulanka and PAN Parks certificate] Master of Science thesis. Finland: University of Oulu.

Zinke, A, G Miller, J Stritih, and P Borg. 2002. PAN Parks 2002: Verification of Oulanka National Park. Finland: Verification report. PAN Parks.

doi:10.1186/2041-7136-2-11

Cite this article as: Heikkinen et al: Users or producers of ecosystem services? A scenario exercise for integrating conservation and reindeer herding in northeast Finland. Pastoralism: Research, Policy and Practice 2012 2:11.

\section{Submit your manuscript to a SpringerOpen ${ }^{\circ}$} journal and benefit from:

- Convenient online submission

Rigorous peer review

- Immediate publication on acceptance

- Open access: articles freely available online

High visibility within the field

- Retaining the copyright to your article

Submit your next manuscript at $\boldsymbol{\nabla}$ springeropen.com 